\title{
Plant mediated methane efflux from a boreal peatland complex
}

\author{
A. Korrensalo (D) I. Mammarella • P. Alekseychik • \\ T. Vesala $\cdot$ E-S. Tuittila
}

Received: 12 April 2021 / Accepted: 6 October 2021 / Published online: 2 December 2021

(C) The Author(s) 2021

\begin{abstract}
Purpose Aerenchymous plants are an important control for methane efflux from peatlands to the atmosphere, providing a bypass from the anoxic peat and avoiding oxidation in the oxic peat. We aimed to quantify the drivers of aerenchymous peatland species methane transport and the importance of this process for ecosystem-scale methane efflux.

Methods We measured seasonal and interspecies variation in methane transport rate per gram of plant dry mass at a boreal fen and bog, which were upscaled to ecosystem-scale plant methane transport. Results Methane transport rate was better explained by plant species, leaf greenness and area than by environmental variables. Leaves appeared to transport
\end{abstract}

Responsible Editor: Luca Bragazza.

Supplementary Information The online version contains supplementary material available at https://doi. org/10.1007/s11104-021-05180-9.

A. Korrensalo $(\bowtie) \cdot$ E.-S. Tuittila

School of Forest Sciences, University of Eastern Finland,

Joensuu, Finland

e-mail: aino.korrensalo@uef.fi

I. Mammarella $\cdot$ P. Alekseychik $\cdot$ T. Vesala Institute for Atmospheric and Earth System Research/ Physics, Faculty of Science, University of Helsinki, Helsinki, Finland

P. Alekseychik

Natural Resources Institute Finland, Helsinki, Finland methane even after senescence. Contrary to our expectations, both methane transport rate and the proportion of plant transport were lower in the fen (with greater sedge cover) than in the bog site. At the fen and bog, average methane transport rate was 0.7 and $1.8 \mathrm{mg} \mathrm{g}^{-1} \mathrm{~d}^{-1}$, and the proportion of seasonally variable plant transport was $7-41 \%$ and $6-90 \%$, respectively. Species-specific differences in methane transport rate were observed at the ecosystem-scale: Scheuchzeria palustris, which accounted for $16 \%$ of the aerenchymous leaf area in the fen and displayed the greatest methane transport rate, was responsible for $45 \%$ of the ecosystem-scale plant transport.

Conclusion Our study showed that plant species influence the magnitude of ecosystem-scale methane emissions through their properties of methane transport. The identification and quantification of these properties could be the pivotal next step in predicting plant methane transport in peatlands.

\author{
T. Vesala \\ Department of Forest Sciences, University of Helsinki, \\ Helsinki, Finland \\ T. Vesala \\ Viikki Plant Science Centre, University of Helsinki, \\ Helsinki, Finland \\ T. Vesala \\ Yugra State University, Khanty-Mansiysk, Russia
}


Keywords Peatland - Plant $\mathrm{CH}_{4}$ transport · Aerenchymous plant $\cdot$ Fen $\cdot$ Bog $\cdot$ Sedge

\section{Introduction}

Wetlands with vegetation that is adapted to water saturated conditions (Pan et al. 2020) are the largest single natural source of methane $\left(\mathrm{CH}_{4}\right)$, the greenhouse gas, (Zhang et al. 2017; Saunois et al. 2020), with a global warming potential 28 to 34 times that of carbon dioxide $\left(\mathrm{CO}_{2}\right)$ on a 100-year timescale (IPCC 2013). Aerenchymous tissue is characteristic to many wetland plants and is an adaptation that provides an oxygen supply to the roots of wetland plants but also acts simultaneously as a major conduit for $\mathrm{CH}_{4}$ efflux to the atmosphere (Fig. 1; Schimel 1995; Pedersen et al. 2021). While the recent increase in the atmospheric $\mathrm{CH}_{4}$ concentration has been partly attributed to wetlands (Kirschke et al. 2013; Zhang et al. 2021), the uncertainties in the estimates of current and future $\mathrm{CH}_{4}$ emissions remain large (O'Connor et al. 2010;
Saunois et al. 2020), which partly results from the poorly quantified mechanisms through which plants impact $\mathrm{CH}_{4}$ oxidation and release, as addressed in modeling work ( $\mathrm{Li}$ et al. 2010; Wania et al. 2010; Zhang et al. 2017; Raivonen et al. 2017).

In northern peat accumulating wetlands (i.e., peatlands), aerenchymous plants are important in regulating $\mathrm{CH}_{4}$ emissions (Fig. 1) as their presence has been observed to lead to lower pore water $\mathrm{CH}_{4}$ concentrations and greater net efflux of $\mathrm{CH}_{4}$ (Green and Baird 2012; Henneberg et al. 2016; Strack et al. 2017). Their abundance is greatest at sites and surfaces where the water level is close to the soil surface (Laine et al. 2012; Korrensalo et al. 2018a; Fig. 1). When $\mathrm{CH}_{4}$ bypasses the oxic peat and live Sphagnum layers via aerenchymous plants, a larger proportion of $\mathrm{CH}_{4}$ produced in the anoxic peat layer may avoid oxidation by the methanotrophic microbes in the aerobic peat layer and be released to the atmosphere (Schimel 1995; Whalen 2005; Turner et al. 2020; Fig. 1). The estimated proportion of plant transport of the total site-level $\mathrm{CH}_{4}$ efflux varies widely from 27 to $98 \%$

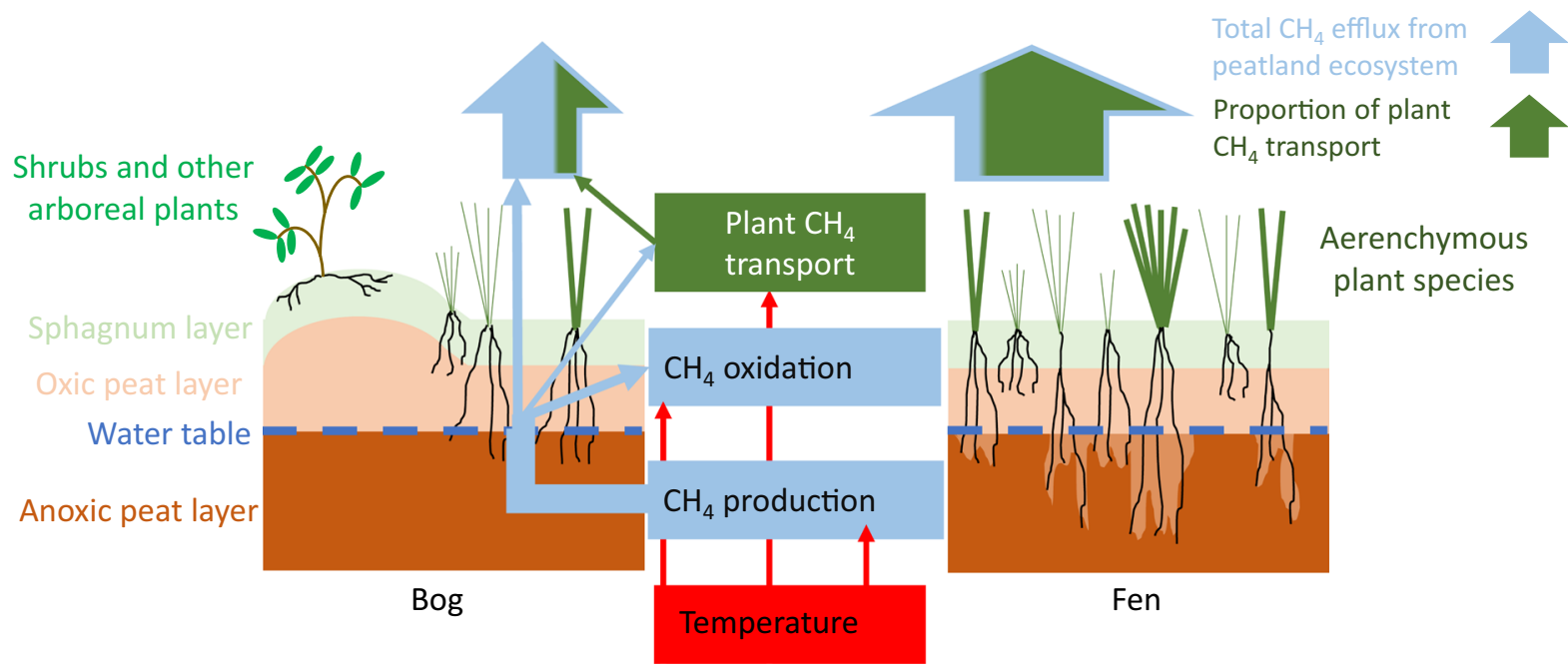

Fig. 1 Schematic presentation of plant methane $\left(\mathrm{CH}_{4}\right)$ transport in fens and bogs; the main peatland types of the boreal region. Vegetation in rainwater-fed, nutrient-poor bogs with a surface topography that varies from shrub dominated drier hummocks to sedge dominated wet hollows provides less suitable litter for methanogenesis than sedge-dominated minerotrophic fens. Sedges and other aerenchymous plant species act as conduits of $\mathrm{CH}_{4}$ to the atmosphere, bypassing oxidation by methanotrophic microbes in the oxic peat and living moss layer, with only negligible oxidation along this bypass route (Turner et al. 2020). Simultaneously, they transport oxygen into the anoxic peat layer (light color around the sedge roots) (Fritz et al. 2011; Münchberger et al. 2019). Both $\mathrm{CH}_{4}$ production and oxidation are regulated by spatially and seasonally varying water levels and soil temperatures (Turetsky et al. 2008; Larmola et al. 2010; Yrjälä et al. 2011), and the same control may also apply to the capacity of plants to transport $\mathrm{CH}_{4}$ (Shannon and White 1994). Aerenchymous plant species may vary in their capacity to transport $\mathrm{CH}_{4}$ (Bhullar et al. 2013) and increase the overall $\mathrm{CH}_{4}$ efflux (Strack et al. 2017), which results in sedge-dominated fens exhibiting greater $\mathrm{CH}_{4}$ emissions than bogs (Turetsky et al. 2014) 
(Morrissey and Livingston 1992; Shannon et al. 1996; Kutzbach et al. 2004; Dorodnikov et al. 2011; Knoblauch et al. 2015). Studying plant $\mathrm{CH}_{4}$ transport over seasonally changing environmental conditions and at sites with different vegetation types might be the key in developing a mechanistic understanding of this process.

A mechanistic understanding of how plants regulate peatland $\mathrm{CH}_{4}$ cycling would improve projections of future $\mathrm{CH}_{4}$ emissions under a changing climate. Climate change will affect the $\mathrm{CH}_{4}$ cycle both directly through changes in abiotic drivers, such as temperature and moisture (Fig. 1), and indirectly through the resultant successional changes in vegetation. In peatlands, vegetation is known to be especially sensitive to changes in hydrology (Talbot et al. 2010; Tahvanainen 2011; Mäkiranta et al. 2018; Kokkonen et al. 2019) and appears to be a stronger control on $\mathrm{CH}_{4}$ cycling than temperature (Ward et al. 2013; Peltoniemi et al. 2016; Riutta et al. 2020). The abiotic and biotic drivers are strongly linked, e.g., once the water table falls below a certain threshold level the impact of vegetation on $\mathrm{CH}_{4}$ fluxes diminishes (Waddington et al. 1996; Strack et al. 2006; Riutta et al. 2020). The change in vegetation resulting from a drier and warmer climate is expected to differ between peatland site types and microforms, causing contrasting impacts on $\mathrm{CH}_{4}$ production. In minerotrophic fens, graminoids could become more abundant (Dieleman et al. 2015), which could support greater $\mathrm{CH}_{4}$ production (Treat et al. 2015), while in rainwater-fed ombrotrophic bogs, a more hostile environment for methanogenesis could result from increased cover of shrubs (Breeuwer et al. 2009), which have recalcitrant litter for decomposition (Bragazza et al. 2013). However, the differences within a wide selection of plant species in $\mathrm{CH}_{4}$ transport has not been previously studied in the field over a growing season to quantify the environmental controls of this process and how it regulates site-scale $\mathrm{CH}_{4}$ efflux. Ongoing climate change and the expected associated successional change in peatland vegetation (Zhang et al. 2020) means that it is essential to know the extent that $\mathrm{CH}_{4}$ transport rate is controlled by plant species and/or environmental conditions.

The aim of our study was to quantify the importance of different aerenchymous plant species and abiotic factors for controlling the plant $\mathrm{CH}_{4}$ transport rate from the peatland to the atmosphere. Further, we aimed to define the importance of $\mathrm{CH}_{4}$ transport for the ecosystem-scale $\mathrm{CH}_{4}$ efflux at a fen and a bog at different times of the growing season. For this, we upscaled plant transport measurements conducted over the growing season at a boreal fen and bog site to the ecosystem-scale and compared our results with eddy covariance (EC) measurements conducted at the two sites. We expected plant $\mathrm{CH}_{4}$ transport rate to be regulated both by species characteristics and by seasonally variable temperature and moisture levels. We also hypothesized that the proportion of the ecosystem-scale $\mathrm{CH}_{4}$ emission attributable to plant $\mathrm{CH}_{4}$ transport would be greater in the fen site, which has a greater cover of aerenchymous species, than in the bog site (Fig. 1).

\section{Materials and methods}

Study site

The study was conducted in two peatland sites, both within the large Siikaneva peatland complex in Ruovesi, western Finland, located in the southern boreal vegetation zone (Ahti et al. 1968). The annual temperature sum in the area is 1318 degree days, annual rainfall is $707 \mathrm{~mm}$, and the average annual, January and July temperatures are 4.2, -7.2 and $17.1{ }^{\circ} \mathrm{C}$, respectively (30-year average values from the Juupajoki-Hyytiälä weather station, located $10 \mathrm{~km}$ from the site).

The bog site, located in the ombrotrophic part of the peatland complex, is characterized by large spatial variation in the water Table (WT) and vegetation composition (Korrensalo et al. 2018a). There is a gradient from high hummocks dominated by dwarfshrubs, a few small Scots pine trees (Pinus sylvestris), and Sphagnum species typical of hummock environments to hollows dominated by ombrotrophic sedges (Carex limosa, Rhynchospora alba) and hollow Sphagna. The bog site also has open water pools and bare peat surfaces, with only a sparse cover of sedges. The fen site, located in the oligotrophic part of the peatland complex, is spatially more homogeneous and dominated by tall sedges (Carex rostrata, $C$. lasiocarpa) and Eriophorum vaginatum (Riutta et al. 2007). For more accurate description of the species 
Fig. 2 The measurement chamber, plexiglass platform and plant sample a) before, and b) after the chamber has been attached on top and tightened with a belt. Soft foam sealant between the platform halves and on the bottom of the chamber ensures the airtightness of the system
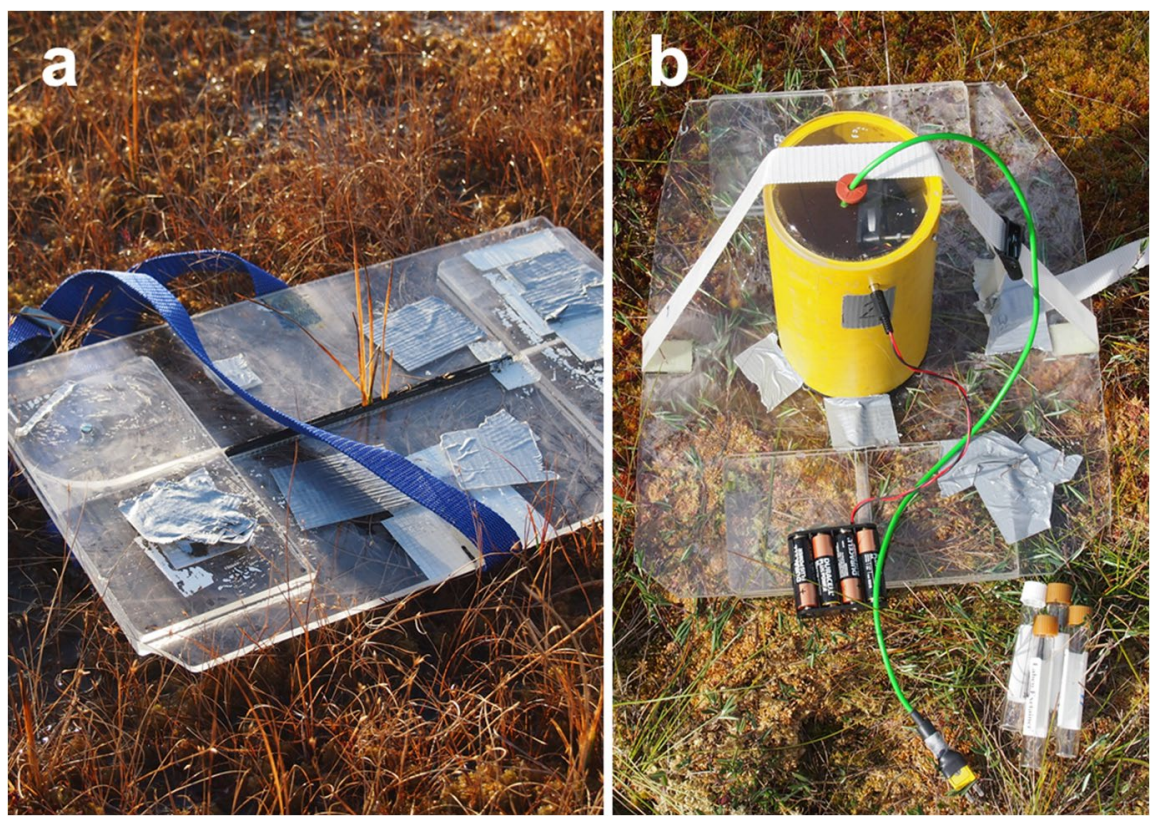

composition at the bog and fen sites, see Korrensalo et al. 2018a and Riutta et al. 2007, respectively. The growing-season average WT in the bog and fen sites is 9 and $15 \mathrm{~cm}$ below the moss surface, respectively (unpublished data from May-September 2019, average of WT values at different vegetation communities, weighted by their areal cover within the sites). In the center of both sites, there is an EC tower reachable by a wooden boardwalk. To compare the WT between years, we used half-hourly WT depths relative to the moss surface that were continuously recorded on an intermediate lawn surface at both sites next to the EC tower. .

Methane efflux measurements

In the bog site, plant $\mathrm{CH}_{4}$ transport rate was measured from all aerenchymous plant species present within the EC tower footprint, namely C. limosa, E. vaginatum, R. alba, Scheuchzeria palustris and Trichophorum cespitosum. In the fen site, measurements were conducted from the four most dominant aerenchymous species; C. lasiocarpa, C. rostrata, E. vaginatum and $S$. palustris, which together accounted for $89 \%$ of the aerenchymous leaf area index (LAI) at the site.

Between June-September in 2013, and May-October in 2014, measurements were carried out on 3-5 samples per species within the EC tower footprint during each campaign, in total 8 and 11 campaigns at the bog site in 2013 and 2014, respectively, and 7 campaigns at the fen site in 2014 . In 2013, the measurements were only carried out at the bog site, but both sites were studied in 2014 . Measurements were conducted from the boardwalk whenever possible to avoid disturbing the peat and prevent $\mathrm{CH}_{4}$ release as ebullition. To ensure that samples of the same species were always located more than $5 \mathrm{~m}$ apart, some measurements were conducted outside of the boardwalks, in which case any walking and movement at the measurement location was avoided.

Plant $\mathrm{CH}_{4}$ transport rate (expressed per gram plant dry mass inside the chamber as $\mathrm{mg} \mathrm{CH}_{4} \mathrm{~g}^{-1}$ day ${ }^{-1}$ ) was measured using custom-made cylinder-shaped chambers that varied in volume between 0.7 and 5.0 1. A plant sample of 2-104 leaves (depending on the growth form of the measured plant) belonging to the same species was separated from the peat and moss underneath, by two plexiglass plates that were attached together with a hinge and had a smooth rubber seal between them to avoid compression of the plant (Fig. 2a). The proportion of green leaves in the sample varied from 0 to $100 \%$ depending on the phase of the growing season. The sample was then covered with an opaque plastic chamber that 
was sealed with the plate by a smooth rubber seal attached to the bottom of the chamber. Airtightness of the system was ensured by tightening a belt that extended from one plate to the other over the chamber. Finally, a rubber stopper was used to seal a vent hole in the top of the chamber (Fig. 2b). Each plant sample was measured for $35 \mathrm{~min}$, during which four $20 \mathrm{ml}$ air samples were drawn from the chamber with a syringe through the rubber stopper in the top of the chamber at 5, 15, 25 and $35 \mathrm{~min}$ after chamber closure. The air samples were then injected into evacuated $12 \mathrm{ml}$ glass vials (Labco Limited, UK).

Simultaneous to the flux measurements, temperatures in the chamber (air) and peat at 5, 15 and $30 \mathrm{~cm}$ depth were recorded. WT was measured from a perforated plastic tube installed into the peat next to the sample after the WT level in the tube had stabilized for at least $30 \mathrm{~min}$. After the flux measurement, the plant sample was cut with scissors and transported to the laboratory in a plastic bag. In each plant sample, the number of leaves was counted, the leaf area of brown and green leaf parts was measured with a scanner, and the dry weight was obtained for brown and green leaf parts separately after oven drying the sample at $60{ }^{\circ} \mathrm{C}$ for $24 \mathrm{~h}$. Using these data, specific leaf area (SLA, $\mathrm{m}^{2} \mathrm{~g}^{-1}$ ) was calculated for each sample.

$\mathrm{CH}_{4}$ concentration in the glass vials was analyzed with an Agilent Technologies 7890A gas chromatograph and Gilson GX-271 liquid handler. The $\mathrm{CH}_{4}$ flux was calculated as the linear change in $\mathrm{CH}_{4}$ concentration in relation to time, chamber volume and temperature. Nonlinear changes in $\mathrm{CH}_{4}$ concentration that were visually detected, were surmised to have resulted from a leak in the chamber or in the vial and were excluded from the analysis. In total $6 \%$ of the measurements were excluded from the final dataset due to such nonlinearities.

In 2014, venting tubes were attached to each chamber to prevent the decrease in pressure inside the chamber when taking the gas samples. The other end of the venting tube was always kept in water during the measurement. These tubes did not significantly impact flux magnitude, which was tested by measuring the same plant samples with and without the tube $(\mathrm{n}=8, \mathrm{p}=0.100)$. Therefore, the data measured with and without the tube (2013 and 2014, respectively) were pooled together.
Statistical methods

A t-test was used to test the significance of differences in plant $\mathrm{CH}_{4}$ transport rates between 2013 and 2014 of all species in the bog site, and the difference in WT levels at the measurement locations of E. vaginatum and $S$. palustris growing in both sites.

We used linear mixed-effects models to quantify the differences in the plant $\mathrm{CH}_{4}$ transport rate between aerenchymous species and sites, and to assess how well the measured plant characteristics and/or environmental variables were able to explain the plant $\mathrm{CH}_{4}$ transport rate. Furthermore, we investigated whether species identity and site are needed to explain the plant $\mathrm{CH}_{4}$ transport rate after environmental variables and measured plant characteristics have been taken into account. First, we constructed a model to assess the differences between species and sites with these two variables as fixed predictors and year and day of the year (DOY) as random effects, after determining that the differences between years and DOY were non-significant. Second, we constructed a model to assess the relative importance of plant characteristics, environmental variables, plant species, and site, where potential fixed predictors were added sequentially. After each new addition, Akaike Information Criterion (AIC) and a conditional F-test were used to evaluate whether the addition significantly improved the model. At this stage, potential fixed predictors for the model were DOY, environmental variables (air temperature, peat temperature at different depths, and WT), and plant characteristics (total leaf area in the sample, number of leaves in the sample, proportion of brown leaves and SLA). Next, we added plant species and site as fixed predictors and checked whether they improved the model. Site, plant species and DOY were included as categorical predictors, while the response shape for the other variables was visually assessed by plotting the residuals of the previous model against the next predictor to be added into the model. The best response shape was then selected using the AIC value and the conditional F-test. In addition to linear and seconddegree polynomial responses, we used a constant response to the explanatory variable, to a visually determined threshold, and a second-degree polynomial response at values smaller or larger than the threshold as a third alternative. The final model 
included the nested random effects of measurement year and DOY. Pairwise comparisons between the levels of categorical predictors were obtained by fitting the model repeatedly but each time holding a different level as a constant to which the other levels were compared. The residuals of the final model were normally distributed around a mean of zero. The model was fitted using function lme of package nlme (Pinheiro and Bates 2000) of R software (version 3.3.2.; R Core Team, 2020). The coefficients of the fixed and random part of the final model are presented in Supplementary information 1.

\section{Eddy covariance measurements}

During the study years, EC measurements were conducted in the bog and fen at a height of $3 \mathrm{~m}$ above the average moss surface. A METEK USA-1 sonic anemometer, a LI-7200 enclosed $\mathrm{CO}_{2}$ and $\mathrm{H}_{2} \mathrm{O}$ gas analyzer and a LI-7700 open-path $\mathrm{CH}_{4}$ analyzer were used in the bog area (Männistö et al. 2019; Alekseychik et al. 2021), while the fen station was equipped with a METEK USA-1 sonic anemometer, a LI-7000 closed path $\mathrm{CO}_{2}$ and $\mathrm{H}_{2} \mathrm{O}$ gas analyzer, and a LGR GGA-24EP closed path $\mathrm{CH}_{4}$ analyzer (Rinne et al. 2018).

The $10 \mathrm{~Hz}$ EC data were processed with the EddyUH software (Mammarella et al. 2016). First, all data were despiked according to Vickers and Mahrt (1997). Then, 2-D rotation was applied to the bog wind velocity components data after Rebmann et al. (2012), while the fen data were processed using a sector-wise planar fit after Mammarella et al. (2007), which was found to yield superior results. The spectral corrections were performed according to Mammarella et al. (2009). The calculated fluxes were filtered by the values of integral turbulence characteristics, skewness, kurtosis, flux stationarity and flux intermittency, following ICOS data processing protocols (Sabbatini et al. 2018; Nemitz et al. 2018). For further information on EC data processing, see Mammarella et al. (2016). The processed $\mathrm{CH}_{4}$ and $\mathrm{CO}_{2}$ fluxes were stored in the units of $\mu \mathrm{mol} \mathrm{m} \mathrm{m}^{-2} \mathrm{~s}^{-1}$. A friction velocity $\left(\mathrm{u}_{*}\right)$ threshold of $0.1 \mathrm{~m} \mathrm{~s}^{-1}$ was imposed on the calculated and quality controlled fluxes to exclude the periods when insufficient turbulent mixing affected the quality of the measured EC fluxes. The $\mathrm{EC} \mathrm{CH}_{4}$ flux was gap-filled using a statistical model based on the relationship between the flux and the peat temperature at a $20 \mathrm{~cm}$ depth; for details, see Alekseychik et al. (2021) (bog site) and Rinne et al. 2018 (fen site).

Estimating site-level aerenchymous leaf area and biomass

Leaf area of aerenchymous plant species was defined in $0.36 \mathrm{~m}^{2}$ sample plots; 18 in the bog site and 15 in the fen site. The sample plots covered the variation in vegetation within the site (Riutta et al. 2007; Korrensalo et al. 2019). Leaf area was estimated every three weeks over the growing seasons following Wilson et al. (2007). The average number of leaves per square meter of each species was estimated by counting the leaf number in five subplots $(8 \times 8 \mathrm{~cm})$. The average size of one leaf was defined with a scanner from samples of corresponding species, which were taken from around the sample plots on each leaf area measurement day. The LAI of each species was defined by multiplying the average number of leaves by the average size of a leaf. Continuous LAI development of each species was then estimated by fitting a loglinear response to the observations (Wilson et al. 2007). Daily LAI values were converted to green biomass (BM, $\mathrm{g} \mathrm{m}^{-2}$ ) using the equations in Korrensalo et al. (2018a) and Mäkiranta et al. (2018). The species-wise daily biomass values at the sample plot scale were upscaled to the ecosystem-scale using the cover of plant community types within the EC tower footprint as presented in Korrensalo et al. (2018a) for the bog site and by Riutta et al. (2007) for the fen site. Total aerenchymous LAI and green biomass $\left(\mathrm{LAI}_{\mathrm{aer}}\right.$ and $\mathrm{BM}_{\text {aer }}$ ) at each site and day was the sum of the species-specific LAI and green BM values.

Upscaling plant $\mathrm{CH}_{4}$ transport

To quantify the proportion of plant $\mathrm{CH}_{4}$ transport rate in the ecosystem-scale $\mathrm{CH}_{4}$ efflux at the two sites, and to quantify the role of different plant species in ecosystem-scale $\mathrm{CH}_{4}$ efflux at different times of the growing season, we upscaled the plant $\mathrm{CH}_{4}$ transport rate $\left(\mathrm{mg} \mathrm{CH} \mathrm{CH}_{4}\right.$ dry mass $\mathrm{g}^{-1}$ day $^{-1}$ ), measured at the plant species-scale, to plant $\mathrm{CH}_{4}$ transport per ground area $\left(\mathrm{g} \mathrm{CH}_{4} \mathrm{~m}^{-2} \mathrm{day}^{-1}\right)$. Daily green BM of each species was multiplied by the seasonal mean plant $\mathrm{CH}_{4}$ transport rate of 
the corresponding species at that site. We used the seasonal mean transport rate for each species in upscaling, because no differences were found in plant $\mathrm{CH}_{4}$ transport rate between the chamber measurement days, seasonally variable temperature or WT (see Results). To make the seasonal estimates comparable between years, we used the same time period from 1st of May to 30th of September for the upscaling at both years and sites. The $\mathrm{CH}_{4}$ transport in the three plant species with low LAI values in the fen site that we did not measure was accounted for in upscaling by multiplying their daily green $\mathrm{BM}$ values by the mean $\mathrm{CH}_{4}$ transport rate for all other fen species. The upscaled plant $\mathrm{CH}_{4}$ transport rates represent only the $\mathrm{CH}_{4}$ transported by the green BM at the sites. Senesced plant biomass data at the sites were not available and it is not known how long the senesced leaves may transport $\mathrm{CH}_{4}$ (based on our measurements).

\section{Results}

Site conditions

In the bog site, where measurements were carried out during 2013 and 2014, WT in the continuous WT recordings at the intermediate lawn surface was lower in the drier year $2013(-14 \mathrm{~cm} \pm 2 \mathrm{~cm}$, May-September mean \pm standard deviation) than in 2014 (WT $-12 \mathrm{~cm} \pm 3 \mathrm{~cm}$ ). In 2014, when measurements were carried out in both sites, the fen site had a growing season (May-September) WT of $-7 \mathrm{~cm} \pm 6 \mathrm{~cm}$ with respect to the lawn surface. The seasonal maximum of $\mathrm{BM}_{\mathrm{aer}}$ was greater in

Table 1 Seasonal cumulative methane $\left(\mathrm{CH}_{4}\right)$ efflux measured by the eddy covariance method and seasonal cumulative ecosystem-scale plant $\mathrm{CH}_{4}$ transport derived from chamber measurements, both calculated for the time period 1.5.-30.9. in 2013
2013 than in 2014 in the bog site (Table 1). The sedge-dominated fen site had a greater $\mathrm{BM}_{\text {aer }}$ value than the bog site during the 2014 growing season (Table 1).

Variability in plant $\mathrm{CH}_{4}$ transport rate

At the bog site, plant $\mathrm{CH}_{4}$ transport rates did not differ between the two measured years $(t=0.50$, $\mathrm{p}=0.615$ ). In the bog site, aerenchymous plants were found to occur at wetter surfaces with shallower average WT than in the fen (Fig. 3c and d).

In the final linear mixed-effects model, plant $\mathrm{CH}_{4}$ transport rate $\left(\mathrm{mg} \mathrm{CH} \mathrm{CH}_{4}\right.$ dry mass $\mathrm{g}^{-1}$ day $^{-1}$ ) was explained by plant species, total leaf area, the proportion of brown leaf area in the sample, and site (Fig. 4a-d). The differences between species largely reflected their habitat along the WT gradient at the two sites; species growing on the wettest surfaces (e.g., S. palustris) showed greater plant $\mathrm{CH}_{4}$ transport rates than species growing on drier surfaces (e.g., $C$. lasiocarpa) (Figs. 3 and 4c). In general, the plant $\mathrm{CH}_{4}$ transport rate was greater at the bog site than at the fen site $(\mathrm{p}=0.002)$. Of the two plant species measured at both the fen and bog in 2014, E. vaginatum was found at similar WT levels and exhibited similar plant $\mathrm{CH}_{4}$ transport rates at both sites, while S. palustris grew in wetter conditions at the bog site and had a significantly greater $\mathrm{CH}_{4}$ transport rate there than at the fen site (Fig. 3c and d). Plant $\mathrm{CH}_{4}$ transport rate was reduced in samples with a greater total leaf area. The response shape that best explained the variability in the data was a second-degree polynomial decrease until LAI reached $18 \mathrm{~cm}^{2}$ and then became constant (Fig. 4b). An increased proportion in brown leaf area decreased the plant $\mathrm{CH}_{4}$ transport rate, but $\mathrm{CH}_{4}$ was

and 2014, seasonal maximum aerenchymous biomass $\left(\mathrm{BM}_{\mathrm{aer}}\right)$ and the proportion of plant $\mathrm{CH}_{4}$ transport in ecosystem-scale $\mathrm{CH}_{4}$ flux in the studied bog and fen sites

\begin{tabular}{lllllll}
\hline Site & Year & $\begin{array}{l}\text { Seasonal } \mathrm{CH}_{4} \text { efflux } \\
(\text { Eddy covariance, } \mathrm{g} \\
\left.\mathrm{CH}_{4} \mathrm{~m}^{-2}\right)\end{array}$ & $\begin{array}{l}\text { Seasonal plant } \mathrm{CH}_{4} \\
\text { transport (chambers, } \mathrm{g} \\
\left.\mathrm{CH}_{4} \mathrm{~m}^{-2}\right)\end{array}$ & $\begin{array}{l}\text { Seasonal } \\
\text { maximum } \mathrm{BM}_{\mathrm{aer}} \\
\left(\mathrm{g} \mathrm{m}^{-2}\right)\end{array}$ & $\begin{array}{l}\text { \% plant transport of } \\
\mathrm{CH}_{4} \text { efflux, mean over } \\
\text { the growing season } \\
\pm 95 \% \mathrm{CI}\end{array}$ & $\begin{array}{l}\text { \% plant transport of } \mathrm{CH}_{4} \\
\text { efflux, min/max over the } \\
\text { growing season }\end{array}$ \\
\hline Bog & 2013 & 10.2 & 4.0 & 31.3 & $35.8 \pm 2.5$ & $5.9 / 59.6$ \\
Bog 2014 & 11.2 & 3.0 & 22.1 & $27.1 \pm 2.2$ & $7.4 / 89.6$ \\
Fen 2014 & 13.1 & 2.8 & 44.4 & $20.8 \pm 1.0$ & $7.4 / 41.2$ \\
\hline
\end{tabular}



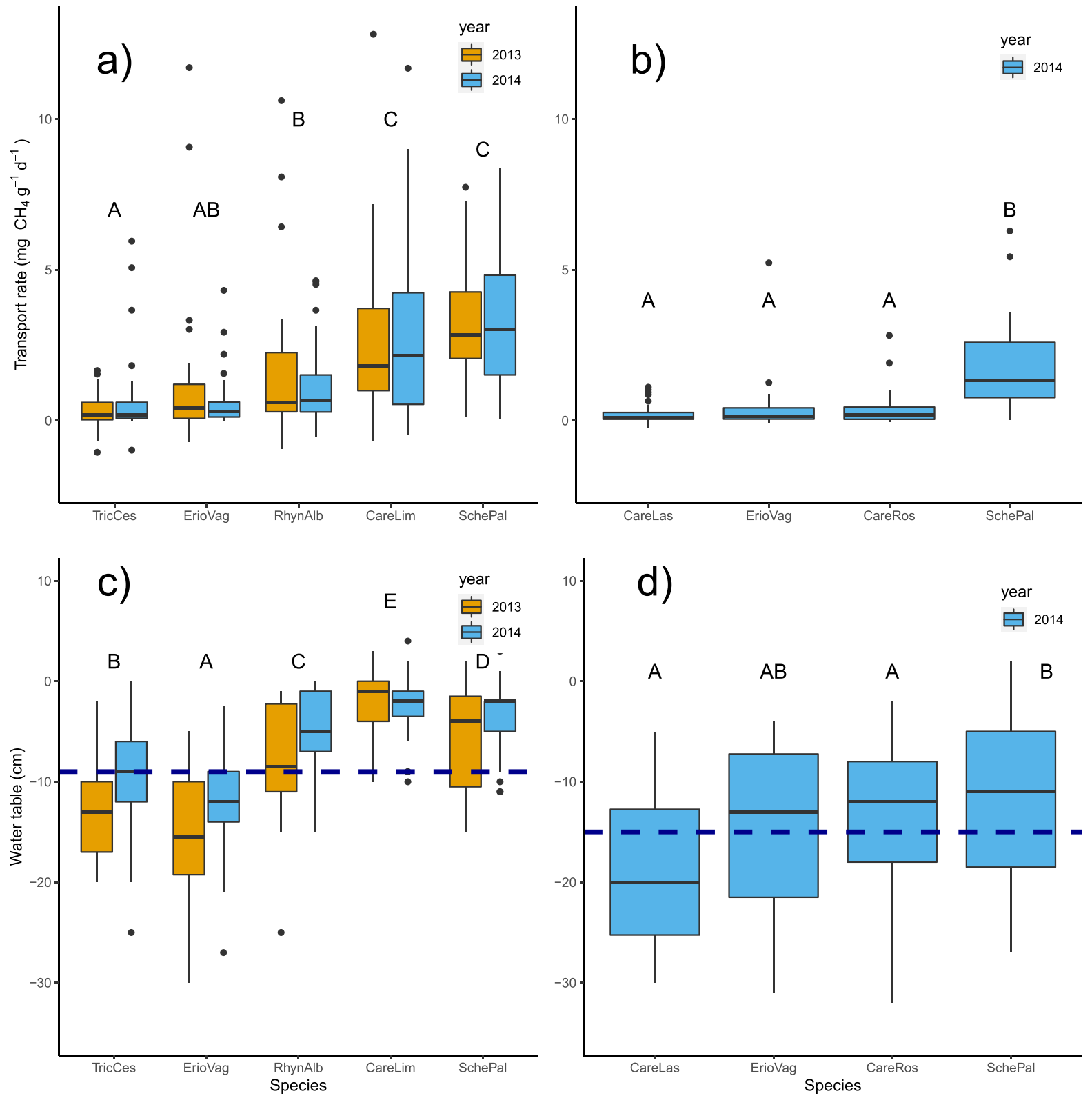

Fig. 3 Differences between aerenchymous plant species in a) and b) methane $\left(\mathrm{CH}_{4}\right)$ transport rate and c) and d) water Table (WT) at the sampling locations at the bog and fen site, respectively. Measurements were conducted in 2013 and 2014 at the bog site, and in 2014 only at the fen site. Upper and lower side of boxes denote the $25 \%$ and $75 \%$ percentiles. Line in the middle of the box denotes the median. The mean WT values at the two sites, measured as distance to the moss surface, are

transported at the non-negligible rate of $0.5 \pm 0.9$ (mean \pm standard deviation) $\mathrm{mg} \mathrm{CH}_{4} \mathrm{~g}^{-1}$ day $^{-1}$ in samples consisting only of brown leaves.

indicated by dark blue dashed lines. Letters denote statistically significant $(\mathrm{p}<0.05)$ differences between plant species. No significant difference was found in $\mathrm{CH}_{4}$ transport rate between measurement years at the bog site. Abbreviated plant species names are TricCes $=$ Trichophorum cespitosum, ErioVag $=$ Eriophorum vaginatum, RhynAlb $=$ Rhynchospora alba, Care$\mathrm{Lim}=$ Carex limosa, SchePal $=$ Scheuchzeria palustris, CareLas $=$ Carex lasiocarpa, CareRos $=$ Carex rostrata

Although a significant response of plant $\mathrm{CH}_{4}$ transport rate to soil temperature at $15 \mathrm{~cm}$ depth and WT was initially detected, the latter abiotic 

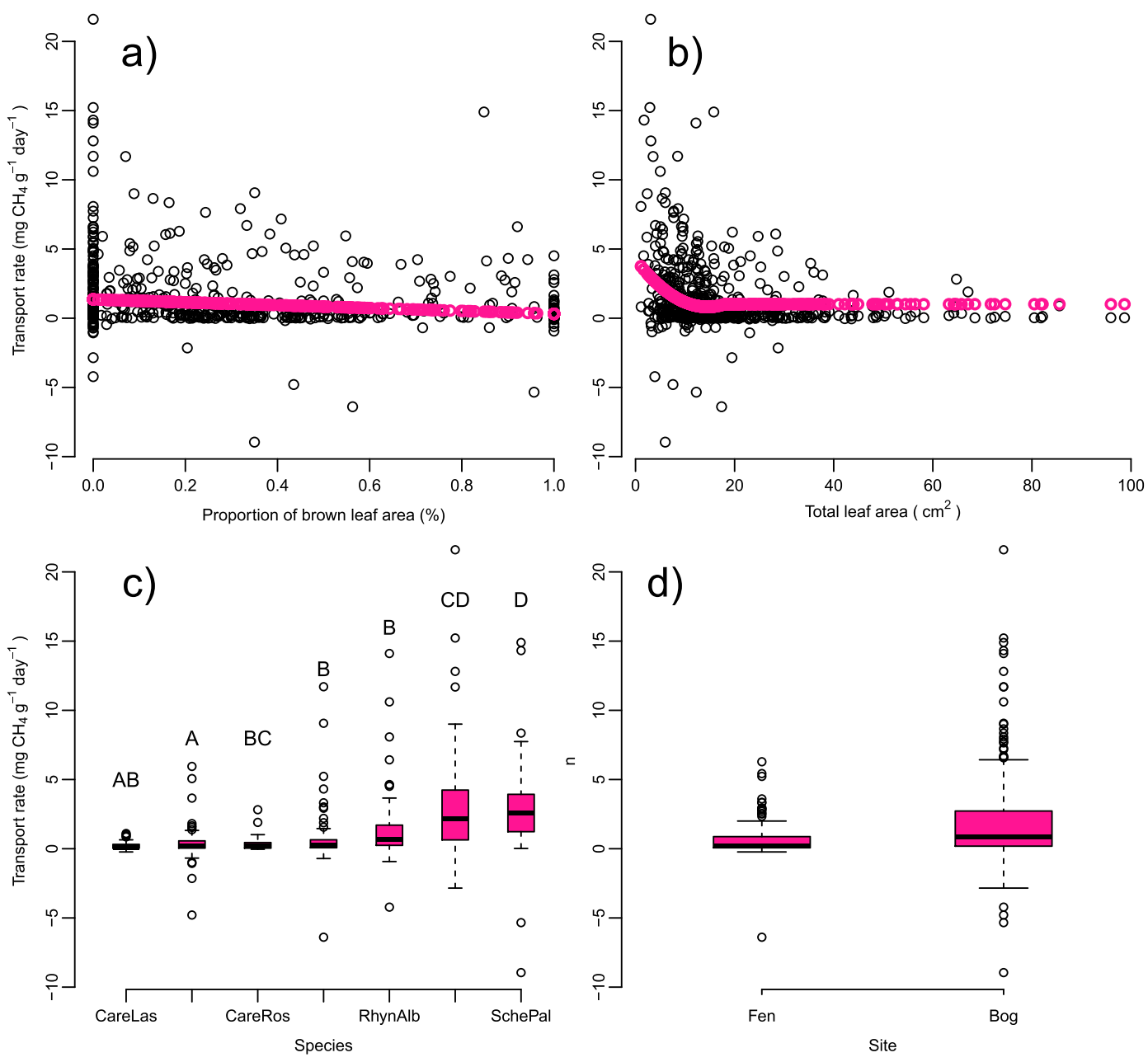

Fig. 4 Variables explaining plant methane $\left(\mathrm{CH}_{4}\right)$ transport and their response according to the linear mixed-effects model. The red datapoints in panels a) and b) show the model prediction when one factor at a time is allowed to vary within the range of the measured data and the other factors are set to constant (proportion of brown leaf area and total leaf area = mean of measured values, species=Eriophorum vaginatum at the bog site),

variables were no longer significant predictors once the variables described in the previous paragraph were included in the model. Brown leaf area was found to be a better predictor of plant $\mathrm{CH}_{4}$ transport rate than peat temperature, and WT no longer significantly explained the plant $\mathrm{CH}_{4}$ transport rate once species was included in the model. In a similar way, SLA and number of leaves were excluded from the model after the more powerful predictors were included.

while the black datapoints represent measured data. Panel c) is based on the measured data from both sites pooled together, and panel d) is based on the measured data from all species and both years pooled together. The letters in panel c) denote statistically significant differences between aerenchymous species based on the mixed-effects model (Appendix 1). Full species names are as in Fig. 3

Impact of species in ecosystem-scale $\mathrm{CH}_{4}$ transport

The extent of total $\mathrm{CH}_{4}$ transport by the different aerenchymous species at the ecosystem-scale was modulated by their $\mathrm{CH}_{4}$ transport rate. For example, S. palustris in the bog site comprised, on average, $13 \%$ of the aerenchymous LAI but accounted for $36 \%$ of total plant $\mathrm{CH}_{4}$ transport due to its rapid $\mathrm{CH}_{4}$ transport rate (Fig. 5a-e). In the fen site, S. palustris contributed on average $16 \%$ of the total aerenchymous LAI but accounted for 

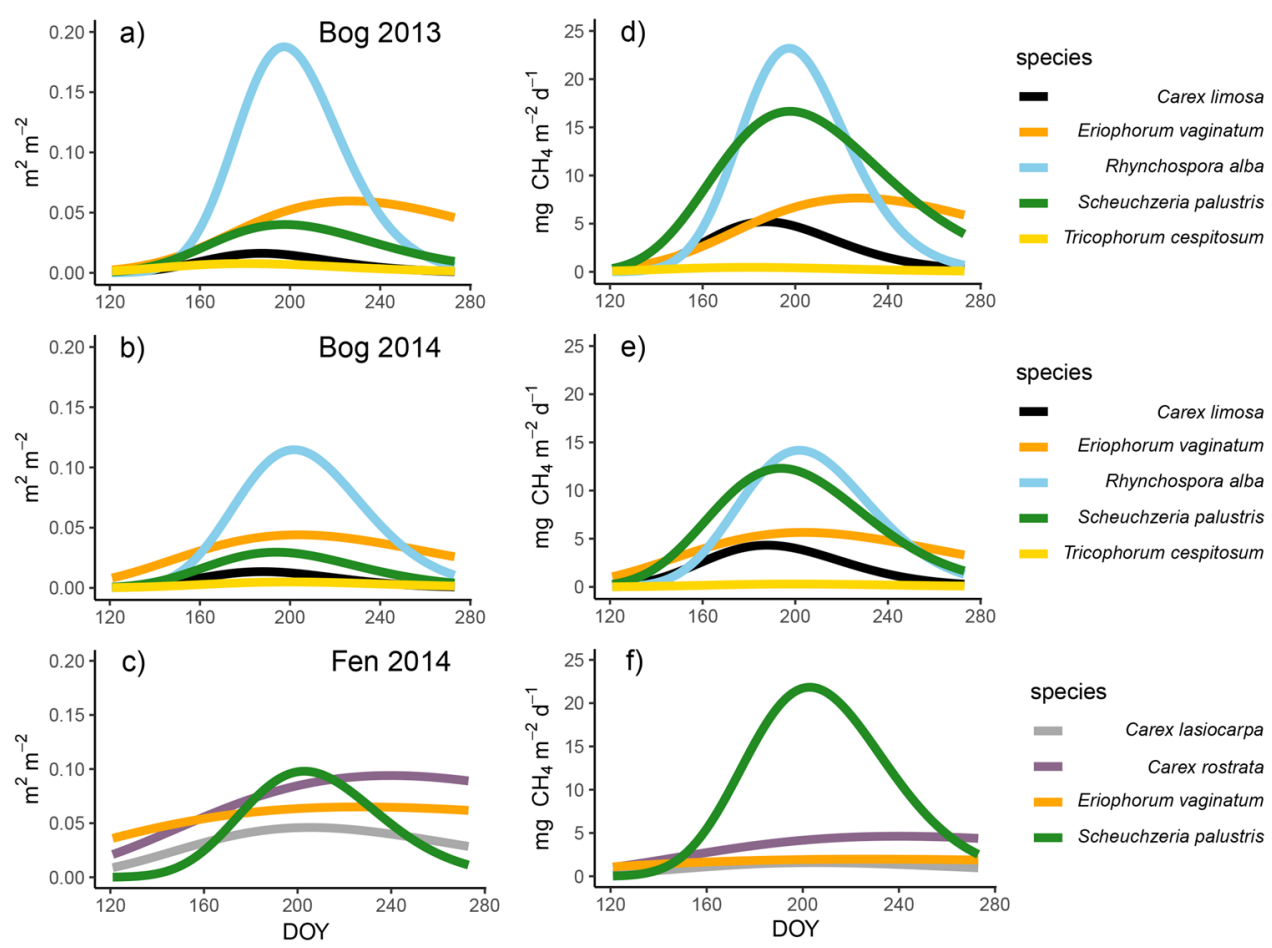

Fig. 5 Seasonal development of reconstructed green leaf area index (LAI) (a-c) and ecosystem-scale methane $\left(\mathrm{CH}_{4}\right)$ transport estimate $(\mathrm{d}-\mathrm{f})$ of each measured aerenchymous species at

$45 \%$ of the total $\mathrm{CH}_{4}$ transport at the site (Fig. 5c and $\mathrm{f}$ ). In contrast, $C$. rostrata in the fen site was observed to have the greatest LAI value for most of the growing season but due to its low $\mathrm{CH}_{4}$ transport rate, exhibited low $\mathrm{CH}_{4}$ transport at the ecosystem-scale.

Proportion of plant $\mathrm{CH}_{4}$ transport of total $\mathrm{CH}_{4}$ efflux

Both the seasonal cumulative plant $\mathrm{CH}_{4}$ transport per ground area $\left(\mathrm{g} \mathrm{CH}_{4} \mathrm{~m}^{-2}\right)$ and its proportion of the total $\mathrm{CH}_{4}$ efflux at the ecosystem-scale were greater in the bog site than in the fen (Table 1, Fig. 6). In the bog, $\mathrm{CH}_{4}$ transport and its proportion were greater in the drier year 2013 than in 2014 (Table 1, Fig. 6). Overall, the daily proportion of plant $\mathrm{CH}_{4}$ transport of the $\mathrm{CH}_{4}$ efflux measured by the $\mathrm{EC}$ tower varied over the growing seasons from 7 to $90 \%$ (Fig. 6). In the fen site, seasonal variation in the proportion of plant $\mathrm{CH}_{4}$ transport, between 7 and $41 \%$ of the daily average $\mathrm{CH}_{4}$ efflux, was the bog site in 2013 ( $a$ and d) and 2014 (b and e), and at the fen site in 2014 (c and f)

much lower than in the bog site in the same year, which exhibited proportions that ranged from 7 to 90\% (Table 1). At both sites, the proportion was generally greatest at the beginning and at the end of the growing season (Fig. 6).

\section{Discussion}

The magnitude of measured $\mathrm{CH}_{4}$ transport rate

The $\mathrm{CH}_{4}$ transport rate values that we measured were in the same range as those reported per gram of plant dry mass by Shannon et al. (1996), which ranged from 1.23-4.49 $\mathrm{mg} \mathrm{CH}_{4} \mathrm{~g}^{-1}$ day $^{-1}$ for a selection of aerenchymous bog plants, while other studies have reported only the rates per leaf area (Schimel 1995). Our values are in agreement with the measurements of Sebacher et al. (1985), although they only reported $\mathrm{CH}_{4}$ emissions from the whole plant. 
Fig. 6 Comparison of eddy covariance-derived daily cumulative estimates of ecosystem-scale methane $\left(\mathrm{CH}_{4}\right)$ efflux and daily plant $\mathrm{CH}_{4}$ transport values upscaled from chamber measurements and daily aerenchymous green leaf area index (LAI) values in a) 2013 at the bog site, b) 2014 at the bog site, and c) 2014 at the fen site
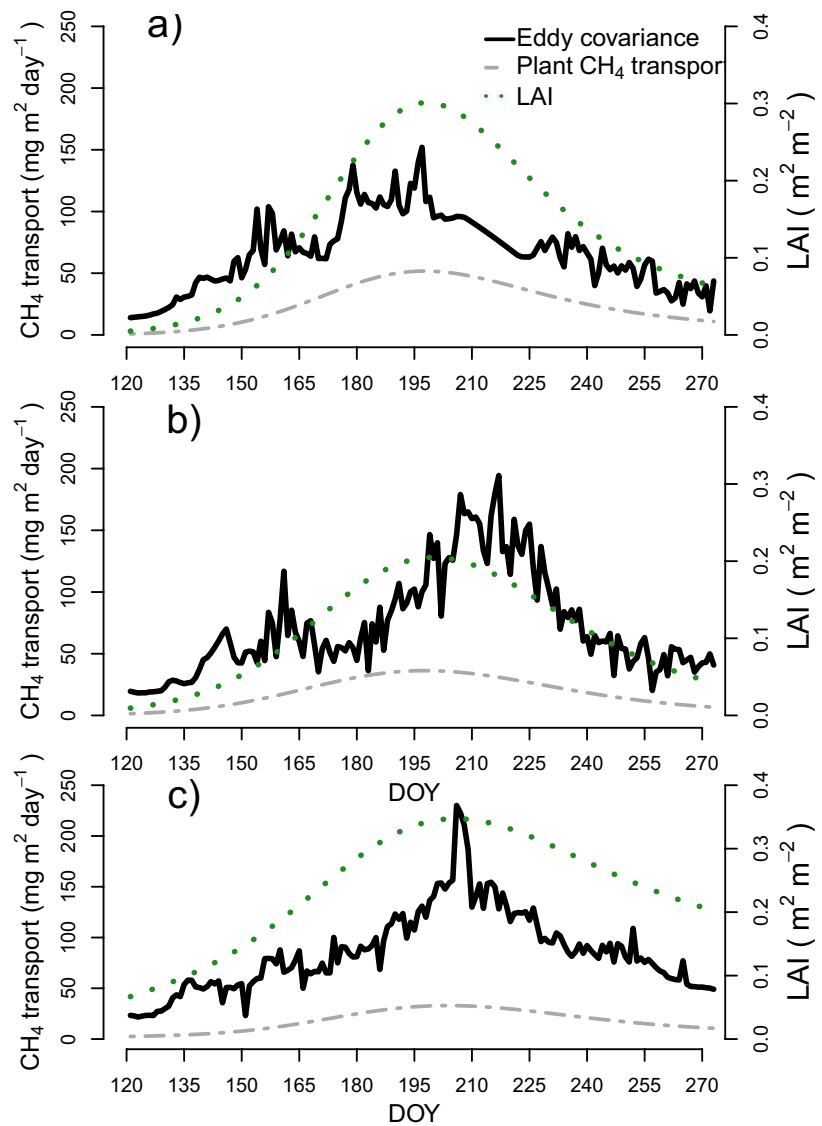

Species rather than environmental factors explain $\mathrm{CH}_{4}$ transport rate

In contrast to our hypothesis, none of the measured abiotic variables were able to explain the plant $\mathrm{CH}_{4}$ transport rate when plant species were included. In our study, which covered a wide selection of aerenchymous plant species at two peatland sites, plant species and their properties (leaf area and proportion of senesced leaves) were better predictors of the $\mathrm{CH}_{4}$ transport rate. These biotic variables correlated with WT and temperature but since they replaced these abiotic variables in the model, they also contain additional information. Peatland plant species have their niche along the WT gradient (Rydin 1993; Väliranta et al. 2007) and, therefore, inherently carry information on the effect of WT on the $\mathrm{CH}_{4}$ transport rate. Wet habitat species, such as $S$. palustris and C. limosa, showed greater $\mathrm{CH}_{4}$ transport rates than hummock species. Accordingly, S. palustris had a reduced $\mathrm{CH}_{4}$ transport rate in the fen site where it grew in drier habitats than in the bog. Similarly, the proportion of brown leaves in the sample was correlated with the seasonal variation of temperature and WT, but displaced them in the final model.

Counterintuitively, total leaf area in the sample was found to decrease the $\mathrm{CH}_{4}$ transport rate. Total leaf area correlates with root biomass (Korrensalo et al. 2018a); root surface area and volume which in turn are known to enhance plant $\mathrm{CH}_{4}$ transport (Henneberg et al. 2012; Bhullar et al. 2013). However, our result is similar to previous studies in mesocosms (Bouchard et al. 2007; Koelbener et al. 2010) that found a negative correlation between $\mathrm{CH}_{4}$ emissions and plant biomass. Greater root density may decrease the proportion of plant transport in total $\mathrm{CH}_{4}$ efflux (Bhullar et al. 2013) as it will bring more oxygen into the anoxic zone and thus stimulate $\mathrm{CH}_{4}$ oxidation in the peat (Ström et al. 2005; Münchberger et al. 2019). Larger and denser tussocks may be able to transport more oxygen into the peat (Fritz et al. 2011). In our 
study, samples with greater leaf area values were often from species that have a tussock-like growth form. As such, our measured $\mathrm{CH}_{4}$ transport rates represented the net effect the plant had on $\mathrm{CH}_{4}$ transport, including also the enhancing effect on oxidation in the peat. Furthermore, with greater aboveground aerenchymous biomass, $\mathrm{CH}_{4}$ in the peat might be distributed between more plants, which would leave less $\mathrm{CH}_{4}$ to transport per unit of biomass.

The addition of plant species improved the explanatory power of our model. This implies that species is a proxy for other biological properties not measured in this study, but which are essential for predicting $\mathrm{CH}_{4}$ transport. Currently, the prediction of various ecosystem functions, such as $\mathrm{CO}_{2}$ cycling, biomass production, and resilience to perturbations, has been attempted using plant functional traits rather than species or plant functional groups (Funk et al. 2017; Rupp et al. 2019). However, work on traits specific to peatland plants has only just begun (Pan et al. 2019, 2020; Pedersen et al. 2021), and the extent that peatland $\mathrm{C}$ dynamics is explained by these traits has rarely been quantified. Net $\mathrm{CH}_{4}$ efflux is known to be related to the presence of aerenchyma in plant tissue (Goud et al. 2017). Our study measured a wide variability in $\mathrm{CH}_{4}$ transport rate between those species that possess aerenchyma tissues, which suggests that possession of aerenchyma alone is not sufficient to quantify the ability of plants to transport $\mathrm{CH}_{4}$. Root traits are known to be important in regulating $\mathrm{CH}_{4}$ transport (Henneberg et al. 2012; Bhullar et al. 2013; Pan et al. 2019, 2020), but they are laborious to measure and cannot be used as a constant value due to withinspecies variability among peatland site types (Metsävainio 1931). This points to the need for further investigation of easily measurable plant functional traits related to $\mathrm{CH}_{4}$ transport and net $\mathrm{CH}_{4}$ emissions in peatland sites. Such traits could be, for example, the diameter of the shoot base, since some species appear to release $\mathrm{CH}_{4}$ at the shoot base (Henneberg et al. 2012), or the diameter of leaf blades from where $\mathrm{CH}_{4}$ commonly exits the plant (Morrissey et al. 1993; Schimel 1995; Kelker and Chanton 1997).

In this study, we observed a potential functional role of dead plant leaves beyond their role as substrate for methanogenesis (Ward et al. 2009). Although $\mathrm{CH}_{4}$ transport rate decreased with the increasing proportion of brown leaves, completely senesced leaves also transported $\mathrm{CH}_{4}$ to the atmosphere. The slower $\mathrm{CH}_{4}$ transport rate of brown leaves could be due to collapsing aerenchymous tissue in the senescing leaves, as well as the overall slower $\mathrm{CH}_{4}$ efflux in spring and autumn (Long et al. 2010; Rinne et al. 2020) when the proportion of brown leaves is greatest. When upscaling the $\mathrm{CH}_{4}$ transport rate, we did not attempt to quantify the role of brown leaves in ecosystem-scale plant $\mathrm{CH}_{4}$ transport, which may have caused a small underestimation in our autumn- and springtime plant transport estimates. In the case of deciduous species, brown leaf area development could be approximately estimated from seasonal peak leaf area, but it is not known how long brown leaves transport $\mathrm{CH}_{4}$ before the collapse of the aerenchyma tissue structure. It is possible that $\mathrm{CH}_{4}$ transport by brown leaves could play a role during warm spells in autumn, when the leaves have only recently senesced and the warm temperatures could stimulate $\mathrm{CH}_{4}$ production.

$\mathrm{CH}_{4}$ transport rate and proportion of plant $\mathrm{CH}_{4}$ transport in fen and bog ecosystems

We observed a slower $\mathrm{CH}_{4}$ transport rate in the aerenchymous species at the fen site with greater ecosystem-scale $\mathrm{CH}_{4}$ efflux than in the bog site. The slower $\mathrm{CH}_{4}$ transport rate observed in the fen plant species could reflect the greater ecosystem-scale aerenchymous biomass resulting in less $\mathrm{CH}_{4}$ to transport per gram of dry mass. Our result is in line with Koelbener et al. (2010), who found that aerenchymous plants in less productive habitats produced greater $\mathrm{CH}_{4}$ emissions than aerenchymous plant species typical of eutrophic sites, possibly due to the quality and quantity of substrate they provide for methanogenesis (greater production of organic acids with low molecular weights).

In contrast to our hypothesis, the fen site with the greater aerenchymous leaf area throughout the growing season accounted for a lower proportion of the total $\mathrm{CH}_{4}$ efflux attributable to plant $\mathrm{CH}_{4}$ transport than the bog site. Our results are also contrary to the model simulation of Raivonen et al. (2017), where the proportion of $\mathrm{CH}_{4}$ efflux attributable to plant transport increased with increasing LAI values. However, in the same model simulations, the proportion of $\mathrm{CH}_{4}$ efflux attributable to plant transport was negatively correlated with the total $\mathrm{CH}_{4}$ efflux at the site (Raivonen et al. 2017), similarly to the fen (greater 
total $\mathrm{CH}_{4}$ efflux) and bog (lower total $\mathrm{CH}_{4}$ efflux) in our study. The same effect was also observed within the growing season, as the proportion of total $\mathrm{CH}_{4}$ efflux attributable to plant transport was greatest when the total efflux was lowest (at the beginning and end of the growing season). Previous studies at the plant community-scale have also demonstrated that plant communities dominated by species with rapid rate of $\mathrm{CH}_{4}$ transport also display greater total $\mathrm{CH}_{4}$ efflux (Morrissey and Livingston 1992; Ding et al. 2005), like the fen and bog sites in our study.

The smaller proportion of the ecosystem-scale $\mathrm{CH}_{4}$ efflux attributable to plant $\mathrm{CH}_{4}$ transport in our fen site could be at least partly explained by differences in $\mathrm{CH}_{4}$ oxidation by methanotrophic microbes. The $\mathrm{CH}_{4}$ oxidation potential has been reported to follow a Gaussian relationship to the growing season median WT of the microhabitat (optimum of about $-3.5 \mathrm{~cm}$ ) (Larmola et al. 2010). The site-level mean WT at the rather wet bog site studied here $(-9 \mathrm{~cm}$, which is also the median) was closer to this optimum than the WT at the fen site $(-15 \mathrm{~cm}$, median $-16 \mathrm{~cm})$. If the efficiency of $\mathrm{CH}_{4}$ oxidation would indeed be greater at the bog site, plant-mediated transport of $\mathrm{CH}_{4}$ past the oxidation zone could compose a larger proportion of ecosystem-scale $\mathrm{CH}_{4}$ efflux than at the fen site, despite the greater $\mathrm{CH}_{4}$ concentration in the fen peat $(21 \%$ and $9 \%$ at $50 \mathrm{~cm}$ depth at the fen and bog, respectively, means of growing season 2018, Korrensalo et al., unpublished data). Therefore, the result could be different when comparing a dry bog to a wet fen. To confirm this, the contribution of plant transport to the overall $\mathrm{CH}_{4}$ efflux at the site-level should be quantified at fen and bog sites with variable WT levels. Another explanation for the result could be the positive relationship between aerenchymous plant cover and rhizospheric oxidation (Münchberger et al. 2019), that may counteract the enhancing effect aerenchymous plant transport has on total $\mathrm{CH}_{4}$ efflux. Further research is needed to find out if there could be an optimum density of aerenchymous plants that maximizes $\mathrm{CH}_{4}$ emission by enhancing $\mathrm{CH}_{4}$ transport and increasing $\mathrm{CH}_{4}$ production through substrate availability, while simultaneously not accelerating rhizospheric oxidation to exceed these processes.
Differences between species in $\mathrm{CH}_{4}$ transport rate impact ecosystem-scale plant $\mathrm{CH}_{4}$ transport

Our estimates were within the same range as previous experimental studies that reported the proportions of total $\mathrm{CH}_{4}$ efflux attributable to plant transport, albeit at the lower end of the previously reported range (Morrissey and Livingston 1992; Whiting and Chanton 1992; Schimel 1995; Kutzbach et al. 2004; Dorodnikov et al. 2011; Knoblauch et al. 2015). However, the clipping of aerenchymous plants that was conducted in some of the previous studies could have led to an overestimation of the proportion of $\mathrm{CH}_{4}$ efflux attributable to plant transport due to simultaneously modifying substrate availability for methanogenesis through the removal of aboveground plant biomass and modifying $\mathrm{CH}_{4}$ oxidation in the peat by cutting off the aerenchymous oxygen transport. Our chamber approach carries the potential error sources in LAI estimation, the conversion of $\mathrm{LAI}$ to $\mathrm{BM}, \mathrm{CH}_{4}$ transport measurements and the spatial vegetation inventory used in upscaling. The reliability of the combination of the two methods used here is supported by the close compatibility of EC measurements and closed chamber measurements upscaled to the ecosystem-scale in the earlier studies conducted in the same fen (Riutta et al. 2007) and bog (Korrensalo et al. 2018b) sites. Furthermore, opaque chambers used to quantify plant $\mathrm{CH}_{4}$ transport create the potential bias by excluding light, which in some studies has been found to impact $\mathrm{CH}_{4}$ efflux, potentially through stomatal closure (Morrissey et al. 1993) and when measuring plants with convective gas transport (Günther et al. 2014), while some studies report no effect of light in Carex-dominated surfaces (Günther et al. 2014; Luan and Wu 2014). However, the reliability of our ecosystem level $\mathrm{CH}_{4}$ transport estimate is supported by the lack of diurnal course in $\mathrm{CH}_{4}$ efflux in earlier studies from the same sites except a mild diurnal temperature effect (Riutta et al. 2007; Rinne et al. 2018; Knox et al. 2021). Further, within a peatland, light has been mainly reported to impact $\mathrm{CH}_{4}$ efflux at dry hummock surfaces (Luan and Wu 2014; Mikkelä et al. 1995) that typically have low cover of aerenchymous species. Despite that, stomatal control of $\mathrm{CH}_{4}$ transport has been suggested to be important only for certain aerenchymous plant species (Schimel et al. 1995), and thus the exclusion of light could potentially impact our $\mathrm{CH}_{4}$ transport estimates through some individual plant species. 
Our study suggests that the differences between plant species in their ability to transport $\mathrm{CH}_{4}$ could have an impact on the ecosystem-scale $\mathrm{CH}_{4}$ efflux. We found that the forb $S$. palustris exhibited the greatest contribution to ecosystem-scale plant $\mathrm{CH}_{4}$ transport in the bog site despite its lesser contribution to ecosystem aerenchymous LAI. Furthermore, our results imply that the transport capacity of aerenchymous species could be a limiting factor for ecosystem-scale $\mathrm{CH}_{4}$ efflux as the $\mathrm{CH}_{4}$ transport rate did not vary over the growing season. Increased soil temperature in the middle of the summer stimulates $\mathrm{CH}_{4}$ production (Dunfield et al. 1993), although a larger fraction of the $\mathrm{CH}_{4}$ may end up oxidized if the transport capacity of the plants is limited. Ebullition is another transport route that bypasses the oxidation zone and is found to occur most in the middle of the summer, as previously reported at our bog site (Männistö et al. 2019). This could be an indicator of limited plant $\mathrm{CH}_{4}$ transport, as ebullition is believed to occur when gas bubbles in the peat become sufficiently large in volume and is triggered by changes in air pressure (Tokida et al. 2007; Chen and Slater 2015), a phenomenon unlikely to happen with an effective plant $\mathrm{CH}_{4}$ transport system.

Current models that describe peatland $\mathrm{CH}_{4}$ cycling typically consider only the bulk biomass or LAI of aerenchymous plants when estimating the role of plant $\mathrm{CH}_{4}$ transport at the ecosystem-scale (Wania et al. 2010; Raivonen et al. 2017), although our work suggests that the inclusion of plant $\mathrm{CH}_{4}$ transport rate is also pivotal. For example, Wania et al. (2010) does not include aerenchymous plants other than sedges in their model due to their small contribution to ecosystem-scale NPP, but as addressed above, certain herbaceous species may contribute significantly to plant $\mathrm{CH}_{4}$ transport. Neglecting species-specific differences in the $\mathrm{CH}_{4}$ transport rate in the current process models could lead to both under- and overestimation of the role of plant transport in ecosystem-scale $\mathrm{CH}_{4}$ efflux, depending on the species composition of the site Some previous studies have found differences in $\mathrm{CH}_{4}$ transport capacity between plant functional types, such as sedges and forbs (Ding et al. 2005; Bhullar et al. 2013). In this study, species belonging to the same plant functional type (sedges) displayed a wide variability in their $\mathrm{CH}_{4}$ transport rates, and previously, even graminoid species of the same family were found to differ in their $\mathrm{CH}_{4}$ transport
(Kao-Kniffin et al. 2010). The intraspecific variability in $\mathrm{CH}_{4}$ transport rate observed here could be another potential error source in the models, although a fuller understanding of this variability requires measurements of a selection of plant species at varying site conditions, such as WT and peat $\mathrm{CH}_{4}$ concentration. Defining separately the transport efficiency and intraspecific variability of all aerenchymous species might be unfeasible, but instead, identifying the traits that correlate with this process might be a better solution from the modeling perspective. Using these traits together with the correlations of $\mathrm{CH}_{4}$ transport rate to WT and peat $\mathrm{CH}_{4}$ concentration could be the key to including these species-specific and intraspecific differences in ecosystem-scale $\mathrm{CH}_{4}$ models.

Acknowledgements We thank Salli Uljas, Janne Sormunen, Laura Kettunen and María Louisa Gutierrez for their assistance with the field measurements, Matti Loponen for help with the gas chromatograph, and the staff at Hyytiälä Forestry Research station for technical assistance. Financial support was received from the Academy of Finland (projects 287039, BORPEAT 330840, SOMPA (312912), CLIMOSS (296116 \& 307192)), Finnish Cultural Foundation, and Faculty of Science and Forestry of University of Eastern Finland, University of Helsinki (ICOS-Finland), VERIFY H2020 EU project and the Tyumen region government in accordance with the Program of the World-Class West Siberian Interregional Scientific and Educational Center (National Project "Nauka").

Availability of data and material The plant $\mathrm{CH}_{4}$ transport data associated with the manuscript has been submitted to PANGAEA repository for publication. On request, the data can also be obtained from the corresponding author. The eddy covariance data is available at SmartSMEAR portal (https:// smear.avaa.csc.fi/). The leaf area data has been published in PANGAEA repository in Korrensalo A, Tuittila E-S, Uljas S (2019): Closed chamber measurements of net ecosystem exchange of $\mathrm{CO} 2$ from Siikaneva bog, Finland. PANGAEA, https://doi.org/10.1594/PANGAEA.905575.

Authors' contributions The study was designed by AK and EST. AK was responsible for the field measurements of plant $\mathrm{CH}_{4}$ transport, data processing and statistical analysis. PA, IM and TV conducted the eddy covariance measurements and processed the data. AK and EST wrote the manuscript with contributions from all other authors.

Funding Financial support was received from the Academy of Finland (projects 287039, BORPEAT 330840, SOMPA (312912), CLIMOSS (296116 \& 307192)), Finnish Cultural Foundation, and Faculty of Science and Forestry of University of Eastern Finland, University of Helsinki (ICOS-Finland) and VERIFY H2020 EU project. Open access funding provided by University of Eastern Finland (UEF) including Kuopio University Hospital. 


\section{Declarations}

Conflicts of interest/competing interests The authors declare no conflicts of interest associated with this manuscript.

Code availability The code used to conduct the statistical analysis is available from the corresponding author on request.

Open Access This article is licensed under a Creative Commons Attribution 4.0 International License, which permits use, sharing, adaptation, distribution and reproduction in any medium or format, as long as you give appropriate credit to the original author(s) and the source, provide a link to the Creative Commons licence, and indicate if changes were made. The images or other third party material in this article are included in the article's Creative Commons licence, unless indicated otherwise in a credit line to the material. If material is not included in the article's Creative Commons licence and your intended use is not permitted by statutory regulation or exceeds the permitted use, you will need to obtain permission directly from the copyright holder. To view a copy of this licence, visit http://creativecommons.org/licenses/by/4.0/.

\section{References}

Ahti T, Hämet-Ahti L, Jalas J (1968) Vegetation zones and their sections in northwestern Europe. Ann Bot Fenn 5:169-211

Alekseychik P, Korrensalo A, Mammarella I et al (2021) Carbon balance of a Finnish bog: temporal variability and limiting factors based on 6 years of eddy-covariance data. Biogeosciences 18:4681-4704. https://doi.org/10.5194/ bg-18-4681-2021

Bhullar GS, Edwards PJ, Olde Venterink H (2013) Variation in the plant-mediated methane transport and its importance for methane emission from intact wetland peat mesocosms. J Plant Ecol 6:298-304. https://doi.org/10.1093/ jpe/rts045

Bouchard V, Frey SD, Gilbert JM, Reed SE (2007) Effects of macrophyte functional group richness on emergent freshwater wetland functions. Ecology 88:2903-2914. https:// doi.org/10.1890/06-1144.1

Bragazza L, Parisod J, Buttler A, Bardgett RD (2013) Biogeochemical plant-soil microbe feedback in response to climate warming in peatlands. Nat Clim Chang 3:273-277. https://doi.org/10.1038/nclimate1781

Breeuwer A, Robroek BJM, Limpens J et al (2009) Decreased summer water table depth affects peatland vegetation. Basic Appl Ecol 10:330-339. https://doi.org/10.1016/j. baae.2008.05.005

Chen X, Slater L (2015) Gas bubble transport and emissions for shallow peat from a northern peatland: the role of pressure changes and peat structure. Water Resour Res 51:151-168. https://doi.org/10.1002/2014WR016268

Dieleman CM, Branfireun BA, McLaughlin JW, Lindo Z (2015) Climate change drives a shift in peatland ecosystem plant community: implications for ecosystem function and stability. Glob Change Biol 21:388-395. https://doi. org/10.1111/gcb.12643
Ding W, Cai Z, Tsuruta H (2005) Plant species effects on methane emissions from freshwater marshes. Atmos Environ 39:3199-3207. https://doi.org/10.1016/j.atmosenv.2005. 02.022

Dorodnikov M, Knorr K-H, Kuzyakov Y, Wilmking M (2011) Plant-mediated $\mathrm{CH}<\mathrm{sub}>4</$ sub $>$ transport and contribution of photosynthates to methanogenesis at a boreal mire: a $<$ sup $>14</$ sup $>$ C pulse-labeling study. Biogeosciences 8:2365-2375. https://doi.org/10.5194/bg-8-2365-2011

Dunfield P, Knowles R, Dumont R, Moore T (1993) Methane production and consumption in temperate and subarctic peat soils: response to temperature and $\mathrm{pH}$. Soil Biol Biochem 25:321-326. https://doi.org/10.1016/0038-0717(93) 90130-4

Fritz C, Pancotto VA, Elzenga JTM et al (2011) Zero methane emission bogs: extreme rhizosphere oxygenation by cushion plants in Patagonia. New Phytol 190:398-408. https:// doi.org/10.1111/j.1469-8137.2010.03604.X

Funk JL, Larson JE, Ames GM et al (2017) Revisiting the holy grail: using plant functional traits to understand ecological processes: plant functional traits. Biol Rev 92:1156-1173. https://doi.org/10.1111/brv.12275

Goud EM, Moore TR, Roulet NT (2017) Predicting peatland carbon fluxes from non-destructive plant traits. Funct Ecol 31:1824-1833. https://doi.org/10.1111/1365-2435.12891

Green SM, Baird AJ (2012) A mesocosm study of the role of the sedge Eriophorum angustifolium in the efflux of methane-including that due to episodic ebullition-from peatlands. Plant Soil 351:207-218. https://doi.org/10. 1007/s11104-011-0945-1

Günther A, Jurasinski G, Huth V, Glatzel S (2014) Opaque closed chambers underestimate methane fluxes of Phragmites australis (Cav.) Trin. Ex Steud. Environ Monit Assess 186:2151-2158. https://doi.org/10.1007/ s10661-013-3524-5

Henneberg A, Brix H, Sorrell BK (2016) The interactive effect of Juncus effusus and water table position on mesocosm methanogenesis and methane emissions. Plant Soil 400:45-54. https://doi.org/10.1007/s11104-015-2707-y

Henneberg A, Sorrell BK, Brix H (2012) Internal methane transport through Juncus effusus : experimental manipulation of morphological barriers to test above- and belowground diffusion limitation. New Phytol 196:799-806. https://doi.org/10.1111/j.1469-8137.2012.04303.x

IPCC (2013) Climate change 2013: the physical science basis. Contribution of working group I to the fifth assessment report of the intergovernmental panel on climate change. Cambridge University press, Cambridge, United Kingdom and New York, NY, USA., 1-1535

Kao-Kniffin J, Freyre DS, Balser TC (2010) Methane dynamics across wetland plant species. Aquat Bot 93:107-113. https://doi.org/10.1016/j.aquabot.2010.03.009

Kelker D, Chanton JP (1997) The effect of clipping on methane emissions from Carex. Biogeochemistry 39:37-44. https:// doi.org/10.1023/A:1005866403120

Kirschke S, Bousquet P, Ciais P et al (2013) Three decades of global methane sources and sinks. Nat Geosci 6:813-823. https://doi.org/10.1038/ngeo1955

Knoblauch C, Spott O, Evgrafova S et al (2015) Regulation of methane production, oxidation, and emission by vascular plants and bryophytes in ponds of the northeast Siberian 
polygonal tundra. J Geophys Res Biogeosci 120:25252541. https://doi.org/10.1002/2015JG003053

Koelbener A, Ström L, Edwards PJ, Olde Venterink H (2010) Plant species from mesotrophic wetlands cause relatively high methane emissions from peat soil. Plant Soil 326:147-158. https://doi.org/10.1007/s11104-009-9989-x

Kokkonen NAK, Laine AM, Laine J et al (2019) Responses of peatland vegetation to 15-year water level drawdown as mediated by fertility level. J Veg Sci 30:1206-1216. https://doi.org/10.1111/jvs.12794

Korrensalo A, Kettunen L, Laiho R et al (2018a) Boreal bog plant communities along a water table gradient differ in their standing biomass but not their biomass production. J Veg Sci 29:136-146. https://doi.org/10.1111/jvs.12602

Korrensalo A, Männistö E, Alekseychik P et al (2018b) Small spatial variability in methane emission measured from a wet patterned boreal bog. Biogeosciences 15:1749-1761. https://doi.org/10.5194/bg-15-1749-2018

Korrensalo A, Mehtätalo L, Alekseychik P et al (2019) Varying vegetation composition, respiration and photosynthesis decrease temporal variability of the $\mathrm{CO} 2$ sink in a boreal bog. Ecosystems. https://doi.org/10.1007/ s10021-019-00434-1

Kutzbach L, Wagner D, Pfeiffer E-M (2004) Effect of microrelief and vegetation on methane emission from wet polygonal tundra, Lena Delta, northern Siberia. Biogeochemistry 69:341-362. https://doi.org/10.1023/B:BIOG.00000 31053.81520.db

Laine AM, Bubier J, Riutta T et al (2012) Abundance and composition of plant biomass as potential controls for mire net ecosytem $\mathrm{CO}_{2}$ exchange. Botany 90:63-74. https://doi. org/10.1139/b11-068

Larmola T, Tuittila E-S, Tiirola M et al (2010) The role of Sphagnum mosses in the methane cycling of a boreal mire. Ecology 91:2356-2365. https://doi.org/10.1890/ 09-1343.1

Li T, Huang Y, Zhang W, Song C (2010) CH4MODwetland: a biogeophysical model for simulating methane emissions from natural wetlands. Ecol Model 221:666-680. https:// doi.org/10.1016/j.ecolmodel.2009.05.017

Long KD, Flanagan LB, Cai T (2010) Diurnal and seasonal variation in methane emissions in a northern Canadian peatland measured by eddy covariance. Glob Change Biol 16:2420-2435. https://doi.org/10.1111/j.1365-2486.2009. 02083.x

Luan J, Wu J (2014) Gross photosynthesis explains the 'artificial bias' of methane fluxes by static chamber (opaque versus transparent) at the hummocks in a boreal peatland. Environ Res Lett 9:105005. https://doi.org/10.1088/17489326/9/10/105005

Mäkiranta P, Laiho R, Mehtätalo L et al (2018) Responses of phenology and biomass production of boreal fens to climate warming under different water-table level regimes. Glob Change Biol 24:944-956. https://doi.org/10.1111/ gcb. 13934

Mammarella I, Kolari P, Rinne J et al (2007) Determining the contribution of vertical advection to the net ecosystem exchange at Hyytiälä forest, Finland. Tellus B: Chemical and Physical Meteorology 59:900-909. https://doi.org/10. 1111/j.1600-0889.2007.00306.x
Mammarella I, Launiainen S, Gronholm T et al (2009) Relative humidity effect on the high-frequency attenuation of water vapor flux measured by a closed-path Eddy covariance system. J Atmospheric Ocean Technol 26:1856-1866. https://doi.org/10.1175/2009JTECHA1179.1

Mammarella I, Peltola O, Nordbo A et al (2016) Quantifying the uncertainty of eddy covariance fluxes due to the use ofdifferent software packages and combinations of processing steps in twocontrasting ecosystems. Atmospheric Meas Tech 9:4915-4933. https://doi.org/10.5194/ amt-9-4915-2016

Metsävainio, K. (1931) Untersuchungen über das wurzelsystem der moorpflanzen. Annales Botanici Societatis Zoologicae-Botanicae Fennicae Vanamo, Helsinki, Finland

Männistö E, Korrensalo A, Alekseychik P et al (2019) Multiyear methane ebullition measurements from water and bare peat surfaces of a patterned boreal bog. Biogeosciences 16:2409-2421. https://doi.org/10.5194/ bg-16-2409-2019

Morrissey LA, Livingston GP (1992) Methane emissions from Alaska Arctic tundra: an assessment of local spatial variability. J Geophys Res Atmospheres 97:16661-16670. https://doi.org/10.1029/92JD00063

Morrissey LA, Zobel DB, Livingston GP (1993) Significance of stomatal control on methane release from Carex-dominated wetlands. Chemosphere 26:339-355. https://doi.org/ 10.1016/0045-6535(93)90430-D

Münchberger W, Knorr K-H, Blodau C et al (2019) Zero to moderate methane emissions in a densely rooted, pristine Patagonian bog - biogeochemical controls as revealed from isotopic evidence. Biogeosciences 16:541-559. https://doi.org/10.5194/bg-16-541-2019

Nemitz E, Mammarella I, Ibrom A et al (2018) Standardisation of eddy-covariance flux measurements of methane and nitrous oxide. International Agrophysics 32:517-549. https://doi.org/10.1515/intag-2017-0042

O'Connor FM, Boucher O, Gedney N et al (2010) Possible role of wetlands, permafrost, and methane hydrates in the methane cycle under future climate change: a review. Rev Geophys 48. https://doi.org/10.1029/2010RG000326

Pan Y, Cieraad E, van Bodegom PM (2019) Are ecophysiological adaptive traits decoupled from leaf economics traits in wetlands? Funct Ecol 33:1202-1210. https://doi.org/10. 1111/1365-2435.13329

Pan Y, Cieraad E, Clarkson BR et al (2020) Drivers of plant traits that allow survival in wetlands. Funct Ecol 34:956967. https://doi.org/10.1111/1365-2435.13541

Pedersen O, Sauter M, Colmer TD, Nakazono M (2021) Regulation of root adaptive anatomical and morphological traits during low soil oxygen. New Phytol 229:42-49. https://doi.org/10.1111/nph.16375

Peltoniemi K, Laiho R, Juottonen H et al (2016) Responses of methanogenic and methanotrophic communities to warming in varying moisture regimes of two boreal fens. Soil Biol Biochem 97:144-156. https://doi.org/10.1016/j.soilb io.2016.03.007

Pinheiro J, Bates D (2000) Mixed-effects models in S and S-PLUS. Springer New York

Raivonen M, Smolander S, Backman L et al (2017) HIMMELI v1.0: HelsinkI model of MEthane buiLd-up and emIssion 
for peatlands. Geosci Model Dev 10:4665-4691. https:// doi.org/10.5194/gmd-10-4665-2017

Rebmann, C., Kolle, O., Heinesch, B., Queck, R., Ibrom, A., and Aubinet, M. (2012) Data acquisition and flux calculation. In: Eddy covariance: a practical guide to measurement and data analysis, Aubinet, M., Vesala, T., and Papale, D. (Eds.), springer Netherlands

Rinne J, Tuittila E-S, Peltola O et al (2018) Temporal variation of ecosystem scale methane emission from a boreal fen in relation to temperature, water table position, and carbon dioxide fluxes. Glob Biogeochem Cycles 32:1087-1106. https://doi.org/10.1029/2017GB005747

Rinne J, Tuovinen J-P, Klemedtsson L et al (2020) Effect of the 2018 European drought on methane and carbon dioxide exchange of northern mire ecosystems. Philos Trans R Soc B Biol Sci 375:20190517. https://doi.org/10.1098/ rstb.2019.0517

Riutta T, Korrensalo A, Laine AM et al (2020) Interacting effects of vegetation components and water level on methane dynamics in a boreal fen. Biogeosciences 17:727-740. https://doi.org/10.5194/bg-17-727-2020

Riutta T, Laine J, Aurela M et al (2007) Spatial variation in plant community functions regulates carbon gas dynamics in a boreal fen ecosystem. Tellus B 59:838-852. https:// doi.org/10.1111/j.1600-0889.2007.00302.x

Rupp D, Kane ES, Dieleman C et al (2019) Plant functional group effects on peat carbon cycling in a boreal rich fen. Biogeochemistry 144:305-327. https://doi.org/10.1007/ s10533-019-00590-5

Rydin H (1993) Interspecific competition between Sphagnum mosses on a raised bog. Oikos 66(3):413-423. https://doi. org/10.2307/3544935

Sabbatini S, Mammarella I, Arriga N et al (2018) Eddy covariance raw data processing for $\mathrm{CO} 2$ and energy fluxes calculation at ICOS ecosystem stations. International Agrophysics 32:495-515. https://doi.org/10.1515/ intag-2017-0043

Saunois M, Bousquet P, Poulter B et al (2016) The global methane budget 2000-2012. Earth Syst Sci Data 8:697751. https://doi.org/10.5194/essd-8-697-2016

Schimel JP (1995) Plant transport and methane production as controls on methane flux from arctic wet meadow tundra. Biogeochemistry 28:183-200. https://doi.org/10.1007/ BF02186458

Sebacher DI, Harriss RC, Bartlett KB (1985) Methane emissions to the atmosphere through aquatic plants. J Environ Qual 14:40-46. https://doi.org/10.2134/jeq1985.00472 425001400010008x

Shannon RD, White JR (1994) A three-year study of controls on methane emissions from two Michigan peatlands. Biogeochemistry 27:35-60. https://doi.org/10.1007/BF000 02570

Shannon RD, White JR, Lawson JE, Gilmour BS (1996) Methane efflux from Emergent vegetation in peatlands. J Ecol 84:239-246. https://doi.org/10.2307/2261359

Strack M, Mwakanyamale K, Hassanpour Fard G et al (2017) Effect of plant functional type on methane dynamics in a restored minerotrophic peatland. Plant Soil 410:231-246. https://doi.org/10.1007/s11104-016-2999-6

Strack M, Waller MF, Waddington JM (2006) Sedge succession and peatland methane dynamics: a potential feedback to climate change. Ecosystems 9:278-287. https://doi.org/ 10.1007/s10021-005-0070-1

Ström L, Mastepanov M, Christensen TR (2005) Speciesspecific effects of vascular plants on carbon turnover and methane emissions from wetlands. Biogeochemistry 75:65-82. https://doi.org/10.1007/s10533-004-6124-1

Sundh I, Svensson BH, Nilsson M (1995) Diurnal variation in methane emission in relation to the water table, soil temperature, climate and vegetation cover in a Swedish acid mire. Biogeochemistry 28:93-114. https://doi.org/ 10.1007/BF02180679

Tahvanainen T (2011) Abrupt ombrotrophication of a boreal aapa mire triggered by hydrological disturbance in the catchment. J Ecol 99:404-415. https://doi.org/10.1111/j. 1365-2745.2010.01778.x

Talbot J, Richard PJH, Roulet NT, Booth RK (2010) Assessing long-term hydrological and ecological responses to drainage in a raised bog using paleoecology and a hydrosequence. J Veg Sci 21:143-156. https://doi.org/ 10.1111/j.1654-1103.2009.01128.x

Tokida T, Miyazaki T, Mizoguchi M et al (2007) Falling atmospheric pressure as a trigger for methane ebullition from peatland. Glob Biogeochem Cycles 21. https://doi. org/10.1029/2006GB002790

Treat CC, Natali SM, Ernakovich J et al (2015) A pan-Arctic synthesis of $\mathrm{CH}_{4}$ and $\mathrm{CO}_{2}$ production from anoxic soil incubations. Glob Change Biol 21:2787-2803. https:// doi.org/10.1111/gcb. 12875

Turetsky MR, Kotowska A, Bubier J et al (2014) A synthesis of methane emissions from 71 northern, temperate, and subtropical wetlands. Glob Change Biol 20:2183-2197. https://doi.org/10.1111/gcb.12580

Turetsky MR, Treat CC, Waldrop MP, et al (2008) Shortterm response of methane fluxes and methanogen activity to water table and soil warming manipulations in an Alaskan peatland. J Geophys Res 113:G00A10. doi: 10.1029/2007JG000496

Turner JC, Moorberg CJ, Wong A, et al (2020) Getting to the Root of Plant-Mediated Methane Emissions and Oxidation in a Thermokarst Bog. J Geophys Res Biogeosciences 125:e2020JG005825. doi: 10.1029/2020JG005825

Väliranta M, Korhola A, Seppä H et al (2007) High-resolution reconstruction of wetness dynamics in a southern boreal raised bog, Finland, during the late Holocene: a quantitative approach. The Holocene 17:1093-1107. https://doi. org/10.1177/0959683607082550

Vickers D, Mahrt L (1997) Quality control and flux sampling problems for tower and aircraft data. J ATMOSPHERIC Ocean Technol 14:15

Waddington JM, Roulet NT, Swanson RV (1996) Water table control of $\mathrm{CH} 4$ emission enhancement by vascular plants in boreal peatlands. J Geophys Res Atmospheres 101:22775-22785. https://doi.org/10.1029/96JD02014

Wania R, Ross I, Prentice IC (2010) Implementation and evaluation of a new methane model within a dynamic global vegetation model: LPJ-WHyMe v1.3.1. Geosci Model Dev 3:565-584. https://doi.org/10.5194/gmd-3-565-2010

Ward SE, Bardgett RD, McNamara NP, Ostle NJ (2009) Plant functional group identity influences short-term peatland ecosystem carbon flux: evidence from a plant removal 
experiment. Funct Ecol 23:454-462. https://doi.org/10. 1111/j.1365-2435.2008.01521.x

Ward SE, Ostle NJ, Oakley S et al (2013) Warming effects on greenhouse gas fluxes in peatlands are modulated by vegetation composition. Ecol Lett 16:1285-1293. https://doi. org/10.1111/ele.12167

Whalen SC (2005) Biogeochemistry of methane exchange between natural wetlands and the atmosphere. Environ Eng Sci 22:73-94. https://doi.org/10.1089/ees.2005.22.73

Whiting GJ, Chanton JP (1992) Plant-dependent CH4 emission in a subarctic Canadian fen. Glob Biogeochem Cycles 6:225-231. https://doi.org/10.1029/92GB00710

Wilson D, Alm J, Riutta T et al (2007) A high resolution green area index for modelling the seasonal dynamics of $\mathrm{CO} 2$ exchange in peatland vascular plant communities. Plant Ecol 190:37-51. https://doi.org/10.1007/ s11258-006-9189-1

Yrjälä K, Tuomivirta T, Juottonen H et al (2011) CH4 production and oxidation processes in a boreal fen ecosystem after long-term water table drawdown: $\mathrm{CH} 4$ production and oxidation processes. Glob Change Biol 17:13111320. https://doi.org/10.1111/j.1365-2486.2010.02290.x

Zhang Z, Zimmermann NE, Stenke A et al (2017) Emerging role of wetland methane emissions in driving 21st century climate change. Proc Natl Acad Sci 114:9647-9652. https://doi.org/10.1073/pnas.1618765114

Zhang Y, Jacob DJ, Lu X et al (2021) Attribution of the accelerating increase in atmospheric methane during 2010 2018 by inverse analysis of GOSAT observations. Atmos Chem Phys 21:3643-3666. https://doi.org/10.5194/ acp-21-3643-2021

Zhang H, Väliranta M, Piilo S et al (2020) Decreased carbon accumulation feedback driven by climate-induced drying of two southern boreal bogs over recent centuries. Glob Chang Biol 26:2435-2448. https://doi.org/10.1111/gcb. 15005

Publisher's note Springer Nature remains neutral with regard to jurisdictional claims in published maps and institutional affiliations. 